\title{
Roska Tamás szerepe a nemzetközi és hazai bionikai kutatásokban ${ }^{1}$
}

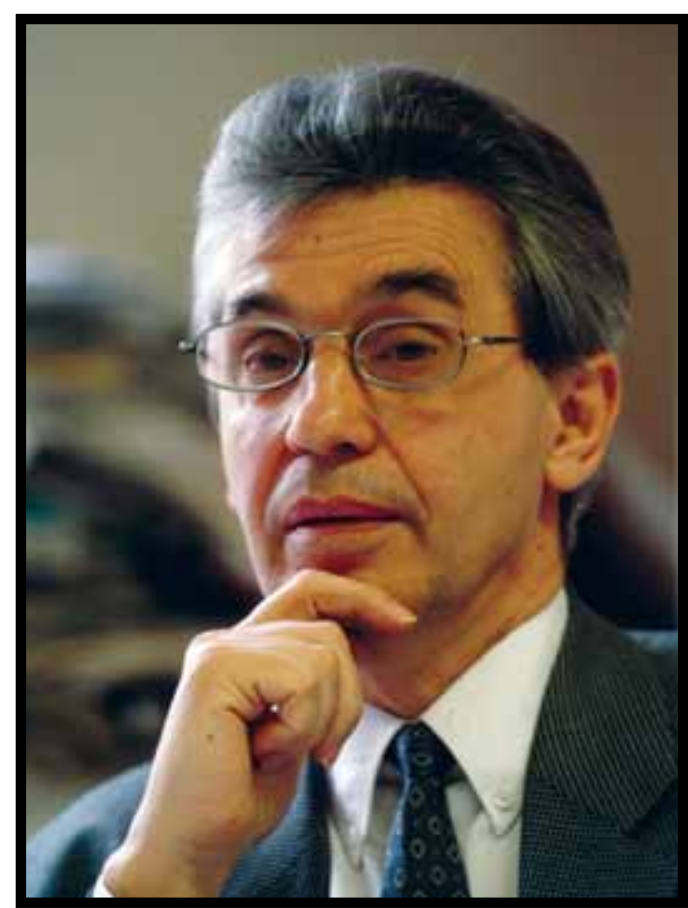

| Prof. Dr. Roska Tamás

Az utóbbi évtizedekben a tudományos kutatás egy új területe alakult ki a múszaki és természettudományok együttmúködésében: az úgynevezett bionika. Multidiszciplináris kutatások, új technikai architektúrák és mindennek a klinikum területére történő implementációja, összekapcsolva az orvostudományt, az idegtudományt, a molekuláris biológiát, a genetikát, az orvosi kémiát, a szerves és szervetlen kémiát, a gyógyszertant és mindezt kiegészítve - legutóbb - a fizika, a nanotechnológia, az optoelektromagnetika, az elektronika és a számítástechnika legújabb eredményeivel, eszközeivel. ${ }^{2}$ A bemutatott felsorolás jól jellemzi, hogy az említett új tudományos kutatási terület lényegében a biológia és az elektronika érintkezési pontjain elhelyezkedő új technológiák felkutatására és fejlesztésére irányul. Ez a természet- és mûszaki tudományok múvelésében - beleértve az orvostudományt is -

${ }^{1}$ Itt köszönöm meg a Pázmány Péter Katolikus Egyetem és a Semmelweis Egyetem által közösen létrehozott Bionikai Innovációs Központ (BIK) tudományos projektjeiben dolgozó minden egyes kutatónak, valamint a BIK minden stratégiai partnerének azokat az adatokat, amelyeket a tanulmány összeállításához felhasználtam.

Jóval részletesebben a lehetséges kutatási projektekről lásd: The 14th International Workshop on Cellular Nanoscale Networks and their Applications (July 29-31, 2014). Jedlik Laboratories Reports, 2014, II(2), 5-65. egy olyan alapvető metodológiai változást jelent, amely egészen újfajta kutatócsoportok létrejöttét eredményezi, és szükséges is, hogy eredményezze. Ezekben a csoportokban együtt dolgoznak a fentebb említett különböző tudományágak képviselői és kutatási területekről érkező szakemberek, akiknek közösen kell tudniuk egy konkrét multidiszciplináris hátteret kívánó kérdés megoldására fókuszálni. Képeseknek kell lenniük arra, hogy egymást segítsék a csoportmunkában, a közös cél elérésében, megosztva kutatótársaikkal azt a sajátos metodológiai és eszközrendszert, amit a saját egyéni területükön használnak. Azonban a csoporton belül - a konkrét multidiszciplináris kérdés megoldásához - minden egyes közremúködő sajátos hátterének a leghatékonyabban kombinált felhasználására van szükség a teljesen új tudományos eredmény eléréséhez. ${ }^{3}$ Az így kifejlesztett új technológiák, minden kétséget kizáróan, forradalmi módon megváltoztatják mind a számítástechnika, mind az egészségügy, a nemzetbiztonság, mind a környezetvédelem (vö. fenntartható fejlődés kérdése) stb. legrelevánsabb területein alkalmazható megoldásokat. Természetesen mindehhez szükséges hozzátennünk a multidiszciplináris metódus által születő, látványosan fejlődő eredmények egyedülállóan innovatív jellegét is, amelyek ipari hatása globálisan kihat a teljes emberi társadalom értékminőségére.

\section{Roska Tamás és víziója}

A fenti bevezető kellőképpen illusztrálja a bionikában rejlő egyedülálló lehetőségeket. Az emberi társadalom történelme folyamán számos tudományos és ipari forradalmat élt át, amelyek pozitív eredményei mind a mai napig gazdagítják azokat az országokat, azokat a tudományterületeket, ipari tevékenységeket vagy éppen szolgáltatásokat (akár az egészségügyet, akár a kutatóintézetekben múködő modellezószoftver-hátteret stb.), ahol meg tudtak honosodni. A felvázolt új technológia kétségkívül egy ilyen új „tudományos forradalmat” jelent, amelybe Magyarország annak legelső stádiumában kapcsolódott be. Ez alapvetően egy személyhez köthető: Roska Tamás akadémikushoz (†2014). ${ }^{4}$

Vö. Roska, T.: The drama of understanding and maintaining hope - in an age of fragmented and multidisciplinary scientific research. In: Vizi, E. S., Kucsera, T. G. (eds.): Europe in a World in Transformation (Conference at the Hungarian Academy of Sciences, 14th-16th December 2006). Budapest, 2008, 93100

Részletesen: Proceedings of the Workshop on Information Technology and Bionics (Symposium in Memory of Tamás Roska, 23-24 June, 2015). Buda pest, 2015. 
Roska Tamás 1940-ben született Budapesten. Az ózdi József Attila Gimnáziumban érettségizett, amely alapvetően meghatározta azt az első baráti kört, akik később a tudományos életben is szellemi partnerei voltak. ${ }^{5} \mathrm{~A}$ második ilyen kört természetesen az egyetemi évek alakították ki, amely tanulmányokat a Budapesti Múszaki Egyetem Villamosmérnöki Karán végezte. Kezdettől fogva a tudományos kutatásnak szentelte az életét, először a Müszeripari Kutató Intézet munkatársaként (19641970), majd a Távközlési Kutató Intézet (1970-1982), végül a Magyar Tudományos Akadémia, Számítástechnikai és Automatizálási Kutatóintézet (SZTAKI) kutatójaként (1982-2014). ${ }^{6} \mathrm{Ez}$ az intézet jelentette számára azt a stabil közeget - a harmadik kör -, amelyben rendkívüli konstruktív és innovatív képességeit fáradhatatlanul és világviszonylatban is kimagaslóan relevánsan tudta kamatoztatni. A nemzetközileg kiemelkedő kutatási habitusa és eredményei már 1989-től lehetővé tették számára a University of California, Berkeleyn elnyert vendégkutatói státuszt, amellyel eredményei nemcsak az Amerikai Egyesült Államokban kerültek a számítástechnikai fejlesztések és kutatások fókuszába, hanem meghozta részére a széles körü, a világ legnevesebb kutatóintézetei által történő ismertséget és elismertséget, valamint a számítástechnikai ipar világviszonylatban vezető szereplőivel való kapcsolatot, amely számos tanácsadó testületi tagságban is megnyilvánult. Mindez katalizátorként hatott Roska Tamás kutatásaira (vö. negyedik kör). A világ legfejlettebb innovatív kutatócentrumaiban és egyetemein elemzett problémák újabb és újabb kutatási irányokra, projektek megindítására, problémamegoldásra és kutatási protokollok létrehozására sarkallták. Azonban ez az az aktivitás, amely teljes tudományos munkásságát a villamosmérnöki területről a legszélesebb multidiszciplináris metódus felé mozdította. Ezt alkalmazta kutatásai során az analogikai és neurális számítógépek forradalmian új fejlesztése terén, amely kutatólaboratóriumnak 1985 és 2011 között vezetője is volt a SZTAKI-n belül. Sőt így jutott el annak a rendszernek a kidolgozásához, amely számára és Leon Chua részére (University of California, Berkeley) - mint társfeltalálók - elhozta a legnagyobb elismerést: a celluláris - nem lineáris - hullámszámítógépek architektúrájának a megalkotása, majd a Cellular Nanoscale Networks (CNN) kifejlesztése. Mindezen kutatásból közvetlenül következett az emberi szervezet, különösen az idegrendszer és a látás biomedicinális megismerése, valamint annak az informatika területén történő alkalmazása. Miközben tehát Roska Tamás mind jobban specifikált tudományos eredményei egyre inkább megkerülhetetlenné tették kutatásait világviszonylatban - amelynek elismeréseként számos kitüntetésben és díjban részesült, beleértve a Gábor Dénes-, a Szent-Györgyi

\footnotetext{
Győry, K.: Egy régi barát visszaemlékezése. In: Roska Tamás 70. születésnapjára. Budapest, 2010, 55-57.

${ }^{6}$ Bársony, I.: Közel negyvenéves kapcsolatunk apropóján. In: Roska Tamás 70. születésnapjára, i. m. 11-14.
}

Albert-, a Széchenyi- és a Bolyai-díjat -, az újonnan kikristályosodott tudományterület, a bionika magyarországi úttörőjévé és annak művelése megszervezőjévé vált.

Már 1993-ban, Hámori József professzorral együttmüködve összeállította és elindította a neuromorf információs technológiai PhD-programot. Azonban a biológiai, kémiai és orvosi területek bevonása a múszaki tudományok múvelésébe ennél jóval átfogóbb szervezést igényelt, amely az ilyen jellegú kutatásra alkalmas generáció magas szintű egyetemi képzésének lehetővé tételét kellett, hogy jelentse. Roska professzor már 1989-1990-ben megszervezte a Veszprémi Egyetemen (ma Pannon Egyetem) a mûszaki informatikai szakot. Az új generáció képzésére a végleges megoldást a Pázmány Péter Katolikus Egyetemen találta meg. Az 1635-ben, Pázmány Péter által alapított egyetem Hittudományi Karát lépésról lépésre új karokkal kiegészítve, a Magyar Katolikus Püspöki Konferencia új, az állam által 1992-ben elismert modern felsőoktatási intézményt alakított ki, amelynek Müszaki Kara megszervezésére Erdō Péter, a PPKE akkori rektora (ma bíboros, Esztergomi-Budapesti Főegyházmegye érseke), 1998-ban Roska Tamást kérte fel. Ő kezdettől fogva nem egy magyarországi hagyományos múszaki kar megszervezésében gondolkodott, hanem - felhasználva mindazt a tapasztalatát, amelyet a hazai és nemzetközi kutatóintézetekben szerzett, valamint jól ismerve a világviszonylatban legjobb egyetemek hatékonyságát biztosító szervezeti kategóriákat - egy Információs Technológiai Kart (ITK) épített ki. A fakultást a 136/2001. (VII. 20.) korm. hat. 3. \$-ával ismerte el az állam; magát a legmodernebb oktatási termekkel, laborokkal és eszközökkel felszerelt épületet pedig 2004-ben adták át. Az új kar éppen azokra a multidiszciplináris metodológiát igénylö, újajta képzési és kutatási koncepciókra épült, amelyeket, többek között, szükséges volt a bionikusképzés hazai magas szintű meghonosításához biztosítani, a hozzá kötődő tudományos-kutatói életmód kialakításaival ötvözve. $\mathrm{Az}$ említett, életének és kutatásainak egyes korszakait meghatározó szellemi körök tagjaiból Roska Tamás a leginnovatívabb oktatói és kutatói állományt hívta egybe, hogy a közös célért - a szükséges infrastrukturális háttér meghatározásával és az egyes specifikus kutatási irányok kellően rugalmas rögzítésével - tudjanak tevékenykedni. Ezzel párhuzamosan elképzeléseinek megvalósíthatóságát a számítástechnika, nanotechnológia és bionika területén a világ vezető kutató- és oktatóintézményeiben vizsgálta, folyamatos együttgondolkodásban a University of California, Berkeley, a University of Notre Dame, a Politecnico di Torino, a Technische Universität Dresden, a Technische Universität München, az Universidad de Sevilla, az Unversidad Miguel Hernández de Elche, az Imperial College (London) és a Catholic University of Leuven vezető kutatóival és oktatóival. Azonban hasonló interaktív kapcsolatot ápolt az MTA releváns kutatóhelyeivel és szakértőivel, továbbá a téma hazai kiválóságaival, mind a Budapesti Múszaki Egyetemen, a Pannon Egyetemen, de sajátosan is a Semmelweis Egyetemen. 
Egyértelműen ennek az eredményeként születhetett meg 2006-ban - Európában elsóként - a molekuláris bionika alapszak a PPKE és a Semmelweis Egyetem (SE) együttmúködésében, amelyet az orvosi biotechnológia MSc és az infobionika mérnök MSc követett. 2009-ben, hosszú fáradozások után, kezdeményezésére létrejöhetett a Magyar Bionikus Látásközpont az SE Szemészeti Klinikája és a PPKE ITK Jedlik Laboratóriumának együttmúködésében. Mindennek a szisztematikus fejlesztésnek, tudatosan irányított, kooperatív és innovatív kutatási tevékenységnek köszönhetően a PPKE ITK 2012-re a bionikai kutatások összehangoló, világviszonylatban elismert központjává vált. Így 2013. január 1-jétől a Roska Tamás által szervezett kar az Információs Technológiai és Bionikai Kar nevet viseli. Utolsó nagy vízióként, szintén 2012-re dolgozta ki a téma legjobb hazai szakértőivel a Bionikai Innovációs Központ (BIK) és a mellette felépülő - az új tudományos képességeket elsajátított szakemberekre és a hozzákapcsolódó iparra építő - Bionikai Innovációs Park (BIP) tervét, amelyet Magyarország kormánya kiemelt állami projektté nyilvánított. ${ }^{7}$

\section{Roska Tamás és a Bionikai Innovációs Központ}

A Bionikai Innovációs Központ létrehozásával mind a PPKE, mind az SE stratégiai lépést tett a hazai - nemzetközi partnerekkel aktívan együttmúködő - bionikai kutatások és fejlesztések minőségi meghonosítása terén. A BIK megszervezésének állam általi elismerését újra a részletes szervezés követte. A tudományos, de egyúttal a kompetitív innovációs kihívás is egyértelmú volt: az új tudományterületen tevékenykedő hazai kutatók számára - akiknek a képzését előző lépcsőként, egészen a PhDszintig intézményes formában lehetővé tette a PPKE és az SE együttmúködése - Magyarországon teremteni olyan kutatási centrumot, amely a bionika területén végzett kutatási projektjeivel relevánsan hozzá tud járulni az új megoldásokat alkalmazni képes innovációs vállalkozásokhoz, de egyúttal szolgáltatást is tud nyújtani, elsősorban a legújabb és nagy értékű orvosdiagnosztikai eszközöknek a betegellátásban történő alkalmazásával. Mindehhez a BIK vezető testületeinek kialakításán és nemzetközi kapcsolatrendszerének megszilárdításán túl, szükséges volt azoknak a fiatal kutatóknak az összefogására, akik csoportmunkában világviszonylatban is új, konstruktív projektekben történő közremúködéssel a BIK-ben folyó munka magas színvonalát és egyúttal hosszú távú fenntarthatóságát is biztosítják. A BIK Tudományos Tanácsának első elnöke Roska Tamás lett, aki 2014. március 18-án ünnepélyes keretek között jelentet-

\footnotetext{
${ }^{7}$ Szuromi, Sz. A.: Tamás Roska and his last vision - Unique Idea to Build an Internationally Competitive Bionics Innovation Center. In: Proceedings of the Workshop on Information Technology and Bionics, i. m. 11-13.
}

te be, hogy az Innovációs Központ megkezdte tudományos kutatótevékenységét. Természetesen, a majdani projektek megvalósítására szolgáló épület - amelynek alapkőletételére 2015. március 26-án került sor - csak 2017-re készül el, a Tudományos Tanács által jóváhagyott kutatási projektek azonban már a hivatalos bejelentés előtt megindultak, és mára komoly eredményt értek el. A BIK által eddig lefedett, jóváhagyott kutatási területek: 1. biomarkerprojekt; ${ }^{8} 2$. Lab-on-a-chip projekt; ${ }^{9}$ 3. a mikroperimetria klinikai használatba történő átültetése ${ }^{10} 4$. orvosbionikai projekt; ${ }^{11} 5$. a Lab-on-achip technológia alkalmazása az élelmiszer-biztonsági elemzésekhez. ${ }^{12}$ Ezen első kutatási projektek monitoringbeszámolóit a Tudományos Tanács folyamatosan ellenőrzi.

\section{Kitekintés}

A Roska Tamásnak köszönhető utolsó elem megvalósulásával teljessé vált az a vízió, hogy Magyarország a bionika területén meghatározó módon tudjon hozzájárulni a világ élvonalában a kutatásokhoz. A számos - hasonló tevékenységet folytató - nemzetközi partnerrel való szoros kapcsolat kiépítése (vö. The Center of Studies and Technical Research [CEIT, San Sebastian], ${ }^{13}$ Center for Applied Medical Research [CIMA, Pamplona], ${ }^{14}$ Gemelli Clinic [Università Sacra Cuore, Roma], University of Notre Dame [Indiana, Amerikai Egyesült Államok]) kiemelten fontos ennek a célnak az eléréséhez. Azonban ugyanezt teszik a PPKE és az SE által közösen megrendezett nemzetközi PhD-konferenciák is, amelyre harmadik alkalommal 2016 novemberében kerül sor. Sőt mindez kiegészül a számos hazai partnerrel történő együttmúködéssel.

Roska Tamás a celluláris - nem lineáris - hullámszámítógépek architektúrájának a megalkotásától eljutott a bionika területének aktív, szakmailag kimagasló múveléséig. Azonban ennél többet is tett: kiépítette Magyarországon ennek az új tudományterületnek mind a szellemi, a képzési, az infrastrukturális, az innovatív és kompetitív alkalmazást lehetővé tevő hátterét. Ezzel munkája a bionika mûvelésének hazai sarkkövévé vált.

Szuromi Szabolcs dr. intézetvezető egyetemi tanár, PPKE

\footnotetext{
${ }^{8}$ https://ppke.hu/uploads/articles/399352/file/BIKBiomarker2014-2.pdf 9 https://ppke.hu/uploads/articles/399352/file/BIKLOChuman2014-1. pdf

10 https://ppke.hu/uploads/articles/399352/file/BIKKlinrendszerinteg2014-1.pdf

${ }^{11}$ https://ppke.hu/uploads/articles/399352/file/BIKOrvosbionika2014v2 pdf

2 https://ppke.hu/uploads/articles/399352/file/BIKLOCelelmiszerbiz tonsag2014.pdf

3 http://www.ceit.es/en/about-ceit/history

${ }^{4}$ https://www.cima.es/areas/neurosciences
} 